\title{
Seasonal Influence on the Essential Oil Variability of Eugenia dysenterica
}

\author{
Alessandra R. Duarte, ${ }^{a}$ Ronaldo R. Naves, ${ }^{b}$ Suzana C. Santos, ${ }^{a}$ José C. Seraphin ${ }^{c}$ and Pedro H. Ferri ${ }^{*}, a$ \\ ${ }^{a}$ Laboratório de Bioatividade Molecular, Instituto de Química, Universidade Federal de Goiás, \\ CP 131, 74001-970 Goiânia-GO, Brazil \\ ${ }^{b}$ Setor de Horticultura, Escola de Agronomia e de Engenharia de Alimentos, Universidade Federal de Goiás,
} CP 131, 74001-970 Goiânia-GO, Brazil

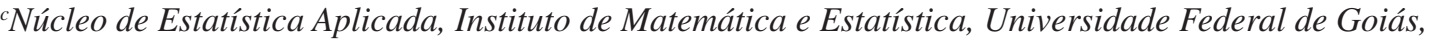
CP131, 74001-970 Goiânia-GO, Brazil

\begin{abstract}
A composição química dos óleos essenciais em populações cultivadas de Eugenia dysenterica, originadas de sementes obtidas de dois diferentes sítios de amostragem, e coletadas durante o verão e o inverno, indicou a presença de dois tipos de óleos, de acordo com a origem das sementes e da estação do ano. O grupo I incluiu somente as amostras oriundas de sementes de Senador Canedo (SC), sejam as coletadas no inverno (subgrupo IA) e caracterizadas pela percentagem elevada de $\beta$-pineno (6,6-14\%), $\alpha$-pineno (5,9-13\%) e (Z)- $\beta$-ocimeno (0-13\%), ou aquelas amostras coletadas principalmente no verão (subgrupo IB) e caracterizadas pela percentagem elevada de $\gamma$-cadineno (0-33\%), limoneno (1,2-28\%) e $\beta$-pineno (3,2-23\%). O grupo II incluiu todas as amostras cultivadas a partir de sementes originadas de Campo Alegre de Goiás (CA), independentemente da estação do ano, cujos constituintes majoritários foram $\beta$-cariofileno (15-74\%), $\delta$-cadineno $(0-24 \%)$ e $\alpha$-copaeno (0-14\%). A correlação canônica entre as populações e as estações do ano revelou que $\alpha$-pineno, (Z)- $\beta$-ocimeno, (E)- $\beta$-ocimeno e $\gamma$-cadineno apresentaram uma forte correlação com o inverno frio e seco (subgrupo IA), enquanto $\beta$-cariofileno, temperatura e precipitação médias mensais foram relacionados às amostras originadas de sementes de CA coletadas durante o verão quente e úmido (grupo II). Os hidrocarbonetos sesquiterpênicos predominaram em todas as populações analisadas e a variação química nos óleos essenciais parece ser determinada geneticamente pela origem da semente, em adição a uma nítida influência sazonal somente sobre aquelas provenientes de SC.
\end{abstract}

The chemical composition of the essential oils of cultivated Eugenia dysenterica populations, which originated from seeds obtained from two different sites and harvested during summer and winter, have indicated the presence of two oil clusters related to seed origin and season. Cluster I included only samples which originated from seeds from Senador Canedo (SC) collected during winter (subcluster IA) and with high percentages of $\beta$-pinene (6.6-14\%), $\alpha$-pinene (5.9-13\%), and (Z)- $\beta$-ocimene (0-13\%), or samples collected mainly in the summer (subcluster IB) and characterized by high contents of $\gamma$-cadinene (0-33\%), limonene (1.2-28\%), and $\beta$-pinene (3.2-23\%). Cluster II included all the samples cultivated from seeds originating from Campo Alegre de Goiás (CA) regardless of the season, which were characterized by high amounts of $\beta$-caryophyllene $(15-74 \%), \delta$-cadinene $(0-24 \%)$, and $\alpha$-copaene $(0-14 \%)$. The canonical correlation between populations and seasons revealed that $\alpha$-pinene, $(Z)-\beta$-ocimene, $(E)-\beta$-ocimene, and $\gamma$-cadinene present a strong correlation with the cold and dry winter (subcluster IA), whereas $\beta$-caryophyllene, temperature, and precipitation were related to samples from CA seed origin during the hot and humid summer (cluster II). Sesquiterpene hydrocarbons predominated in all the sampled populations and the observed essential oil chemovariation might be genetically determined by seed origin, in addition to a clear seasonal influence shown only in the samples from SC seeds.

Keywords: Eugenia dysenterica, Myrtaceae, essential oil, chemical variability, multivariate analysis, seasonal influence

*e-mail: pedro@quimica.ufg.br 


\section{Introduction}

Eugenia genus is distributed throughout all Brazilian regions and consists of about 500 species of trees and shrubs with aromatic foliage and some edible cherry-like fruits. ${ }^{1}$ In the Brazilian Cerrado, E. dysenterica DC. (syn. Stenocalyx dysentericus Berg., Myrtus dysenterica M.) grows wild or is cultivated because of its appreciated fruits which are consumed in natura or processed to produce different kinds of jams and ice creams, although they are used only in an extractive and predatory manner. ${ }^{2}$ Their leaves are well-known within Brazilian Cerrado medicine as part of preparations used for medical diarrhoeic care and dysentery. ${ }^{3}$ Antimicrobial activities have been reported for the essential oils and pressed juice of the Eugenia genus, including dermatophytes, ${ }^{4}$ antibacterial,${ }^{5}$ and systemic fungi. ${ }^{6,7}$

Various studies concerning the genetic diversity of $E$. dysenterica wild populations have shown a complex pattern of genetic variation in the geographical space which can be used for the germplasm conservation of this species in ex situ and in situ conditions. ${ }^{8,9}$

Previous chemical investigations have been restricted to essential oils from leaves and to the dynamics of terpene variations during the fruit ripening period of this species. ${ }^{6,10}$ Despite the great potential and the growing regional market for $E$. dysenterica, seasonal variation in the essential oil composition has not yet been reported.

We now report on the results obtained for the composition and seasonal variability of the leaf essential oil of $E$. dysenterica that was collected from cultivated populations originating from seeds obtained from two different sites in the Central Brazilian Cerrado. For this purpose, essential oils from leaves of representative population samples of each seed origin during different seasons were analyzed by GC-MS. In order to study chemical variability, chemical constituents were submitted to multivariate chemometric analyses such as principal component (PCA) and cluster and canonical discriminant (CDA) in order to detect the distribution pattern of samples and to identify which chemical constituents are able to distinguish between these groups of individuals. In addition, seasonal factors affecting essential oil variability between the oil constituent data set and the climactic data matrix for each season were analyzed by canonical correlation analysis.

\section{Results and Discussion}

In the present work, E. dysenterica leaf oils were obtained from cultivated plants originating from seeds obtained from two native populations that were geographically separated by the Corumbá River basin, which forms two spatially discontinuous sampling sites in the cities of Senador Canedo (SC) and Campo Alegre de Goiás (CA). The cultivated plants were made up of 12-year-old individuals obtained by seed propagation from indigenous populations in an experimental field located 30 and $200 \mathrm{~km}$ from the natural SC and CA populations, respectively.

Unlike other studies in the literature which state that plants exhibit remarkable fluctuation in oil contents with the progress of seasons, ${ }^{11,12}$ the mean oil yields failed to show statistically significant differences in relation to seed origin and season. On the other hand, the chemical composition of $E$. dysenterica oils differed considerably with regard to the seasons (Table 1). With the exception of humidity ( $p<0.163)$, all climatic variables varied significantly $(p<0.0001)$ as seasons changed. In total, 29 compounds were identified, accounting for $78 \%-100 \%$ of volatile constituents. All essential oils predominantly reveal sesquiterpene hydrocarbon compositions (58\%-78\%) even though the monoterpene hydrocarbon content for some samples originating from SC seeds is over $59 \%$. These results are in accordance with those obtained by Costa et al. ${ }^{6}$ who reported sesquiterpene hydrocarbons as major constituents.

The effects of samples seed origin and/or the season on the essential oil constituents were evaluated by a two-way analysis of variance (ANOVA). The combined influence of the two effects (interaction effects), the predominance of only one (without interaction), or the absence of both is shown in Table 1. Two-way ANOVA indicated that important differences in the amounts of major constituents were found according to the interaction between seed origin and season, such as limonene (4) $(0.94 \%)$, with the lowest amount during the wet season in samples originating from CA seeds; $\beta$-caryophyllene (10) (37\%), sesquiterpenes $(86 \%)$, and sesquiterpene hydrocarbons $(78 \%)$, which had the highest percentage during the wet season in samples from CA seed origin; and $\delta$-cadinene (26) (13\%-14\%) in samples cultivated from CA seeds regardless of the season. Quantitative chemical differences were found according to seed origin and season but were devoid of any interaction as $\alpha$-pinene (1) (8.0\%) and monoterpenes (33\%), which revealed the highest amounts from samples originating from SC seeds regardless of the season; or during the dry season regardless of the seed origin of samples, as $\alpha$-pinene (1) $(7.7 \%)$ and monoterpenes (24\%). On the other hand, quantitative differences were also obtained solely between seed origin of samples as in $\beta$-pinene (2) (8.5\%), $\gamma$-cadinene (24) (14\%), and monoterpene hydrocarbons (32\%), which showed the highest percentage in samples originating from SC seeds, whereas $\alpha$-copaene (9) (8.7\%), caryophyllene 
Table 1. Percentages ${ }^{\mathrm{a}}(\%)$ of essential oil constituents from cultivated $E$. dysenterica from seeds from two different sites and collected during dry and wet seasons in the Brazilian Cerrado

\begin{tabular}{|c|c|c|c|c|c|}
\hline \multirow{2}{*}{ Constituent } & \multirow{2}{*}{$\mathrm{RI}^{\mathrm{b}}$} & \multirow{2}{*}{ Season } & \multicolumn{2}{|c|}{ Seed origin } & \multirow{2}{*}{ Average } \\
\hline & & & SC & $\mathrm{CA}$ & \\
\hline \multirow{3}{*}{$1 \alpha$-Pinene ${ }^{c}$} & \multirow{3}{*}{933} & Dry & 8.2 & 7.3 & $7.7 \mathrm{~A}$ \\
\hline & & Wet & 7.9 & 3.8 & $5.8 \mathrm{~B}$ \\
\hline & & Average & $8.0 \mathrm{a}$ & $5.3 \mathrm{~b}$ & \\
\hline \multirow{3}{*}{$2 \beta$-Pinene ${ }^{\mathrm{c}, \mathrm{d}}$} & \multirow{3}{*}{978} & Dry & 8.3 & 4.0 & $5.9 \mathrm{~A}$ \\
\hline & & Wet & 8.6 & 2.9 & $5.6 \mathrm{~A}$ \\
\hline & & Average & $8.5 \mathrm{a}$ & $3.4 \mathrm{~b}$ & \\
\hline \multirow{3}{*}{3 Myrcene $^{\mathrm{d}}$} & \multirow{3}{*}{989} & Dry & 2.1 & 0.59 & $1.3 \mathrm{~A}$ \\
\hline & & Wet & 2.3 & 0.83 & $1.5 \mathrm{~A}$ \\
\hline & & Average & $2.2 \mathrm{a}$ & $0.72 \mathrm{~b}$ & \\
\hline \multirow{2}{*}{4 Limonene $^{\mathrm{c}, \mathrm{d}}$} & \multirow{2}{*}{1025} & Dry & $6.3 \mathrm{Aa}$ & $1.8 \mathrm{Aa}$ & \\
\hline & & Wet & $14 \mathrm{Aa}$ & $0.94 \mathrm{Bb}$ & \\
\hline \multirow{3}{*}{$5(Z)-\beta$-Ocimene ${ }^{c}$} & \multirow{3}{*}{1035} & Dry & 4.7 & 2.3 & $3.4 \mathrm{~A}$ \\
\hline & & Wet & 0.03 & 2.0 & $1.1 \mathrm{~A}$ \\
\hline & & Average & $1.9 \mathrm{a}$ & $2.1 \mathrm{a}$ & \\
\hline \multirow{3}{*}{$6(\mathrm{E})-\beta$-Ocimene ${ }^{\mathrm{c}, \mathrm{e}}$} & \multirow{3}{*}{1045} & Dry & 1.6 & 0.46 & $0.96 \mathrm{~A}$ \\
\hline & & Wet & 0.54 & 0.44 & $0.49 \mathrm{~B}$ \\
\hline & & Average & $0.96 \mathrm{a}$ & $0.45 \mathrm{~b}$ & \\
\hline \multirow{3}{*}{7 Linalool $^{\mathrm{c}}$} & \multirow{3}{*}{1098} & Dry & 0.52 & 0.29 & $0.39 \mathrm{~A}$ \\
\hline & & Wet & 0.30 & 0.17 & $0.23 \mathrm{~A}$ \\
\hline & & Average & $0.39 \mathrm{a}$ & $0.22 \mathrm{a}$ & \\
\hline & & Dry & 0.44 & 0.97 & $0.73 \mathrm{~A}$ \\
\hline $8 \alpha$-Terpineol ${ }^{\mathrm{e}}$ & 1189 & Wet & 0.06 & 0.23 & $0.15 \mathrm{~B}$ \\
\hline & & Average & $0.21 \mathrm{a}$ & $0.56 \mathrm{~b}$ & \\
\hline & & Dry & 2.8 & 9.1 & $6.3 \mathrm{~A}$ \\
\hline $9 \alpha$-Copaene ${ }^{c}$ & 1376 & Wet & 0.03 & 8.4 & $4.4 \mathrm{~A}$ \\
\hline & & Average & $1.2 \mathrm{a}$ & $8.7 \mathrm{~b}$ & \\
\hline 10 $\beta$ C Tryollenoc,d & 1421 & Dry & $22 \mathrm{Aa}$ & $22 \mathrm{Aa}$ & \\
\hline $10 \mathrm{p}$-cal yopinymente & 1421 & Wet & $24 \mathrm{Aa}$ & $37 \mathrm{Bb}$ & \\
\hline & & Dry & 1.1 & 1.5 & $1.3 \mathrm{~A}$ \\
\hline $11 \alpha$-Guaiene ${ }^{d}$ & 1439 & Wet & 0.17 & 1.0 & $0.60 \mathrm{~B}$ \\
\hline & & Average & $0.54 \mathrm{a}$ & $1.2 \mathrm{a}$ & \\
\hline & & Dry & 1.3 & 0.26 & $0.73 \mathrm{~A}$ \\
\hline 12 6,9-Guaiadiene ${ }^{\mathrm{e}}$ & 1445 & Wet & 1.2 & 0.44 & $0.80 \mathrm{~A}$ \\
\hline & & Average & $1.2 \mathrm{a}$ & $0.36 \mathrm{~b}$ & \\
\hline & & Dry & 1.8 & 0.51 & $1.1 \mathrm{~A}$ \\
\hline $13 \alpha$-neo-Clovene $e^{\mathrm{c}, \mathrm{e}}$ & 1451 & Wet & 3.0 & 0.54 & $1.7 \mathrm{~A}$ \\
\hline & & Average & $2.5 \mathrm{a}$ & $0.53 \mathrm{~b}$ & \\
\hline & & Dry & 8.9 & 13 & $11 \mathrm{~A}$ \\
\hline $14 \alpha$-Humulene ${ }^{c}$ & 1455 & Wet & 8.5 & 13 & $11 \mathrm{~A}$ \\
\hline & & Average & $8.6 \mathrm{a}$ & $13 \mathrm{a}$ & \\
\hline & & Dry & 0.42 & 0.74 & $0.60 \mathrm{~A}$ \\
\hline $15 \gamma$-Muurolene & 1476 & Wet & 0.03 & 0.66 & $0.36 \mathrm{~A}$ \\
\hline & & Average & $0.19 \mathrm{a}$ & $0.69 \mathrm{a}$ & \\
\hline & & Dry & 0.01 & - & 0.01 \\
\hline $16 \alpha$-Amorphene & 1481 & Wet & 0.27 & 0.17 & 0.22 \\
\hline & & Average & $0.16 \mathrm{a}$ & $0.10 \mathrm{a}$ & \\
\hline & & Dry & 0.63 & 0.52 & $0.57 \mathrm{~A}$ \\
\hline $17 \beta$-Selinene ${ }^{\mathrm{e}}$ & 1487 & Wet & 0.20 & 0.21 & $0.20 \mathrm{~B}$ \\
\hline & & Average & $0.38 \mathrm{a}$ & $0.34 \mathrm{a}$ & \\
\hline & & Dry & 2.0 & 3.1 & $2.6 \mathrm{~A}$ \\
\hline $18 \delta$-Selinene ${ }^{\mathrm{e}}$ & 1491 & Wet & 2.0 & - & $0.95 \mathrm{~A}$ \\
\hline & & Average & $2.0 \mathrm{a}$ & $1.4 \mathrm{a}$ & \\
\hline
\end{tabular}

\begin{tabular}{|c|c|c|c|c|c|}
\hline \multirow{2}{*}{ Constituent } & \multirow{2}{*}{$\mathrm{RI}^{\mathrm{b}}$} & \multirow{2}{*}{ Season } & \multicolumn{2}{|c|}{ Seed origin } & \multirow{2}{*}{ Average } \\
\hline & & & $\mathrm{SC}$ & $\mathrm{CA}$ & \\
\hline \multirow{3}{*}{$19 \alpha$-Selinene } & \multirow{3}{*}{1496} & Dry & 0.55 & 0.65 & $0.61 \mathrm{~A}$ \\
\hline & & Wet & 0.37 & 0.38 & $0.39 \mathrm{~A}$ \\
\hline & & Average & $0.44 \mathrm{a}$ & $0.50 \mathrm{a}$ & \\
\hline \multirow{3}{*}{20 Bicyclogermacrene } & \multirow{3}{*}{1500} & Dry & 0.56 & - & $0.25 \mathrm{~A}$ \\
\hline & & Wet & 0.09 & - & $0.04 \mathrm{~B}$ \\
\hline & & Average & 0.28 & - & \\
\hline \multirow{3}{*}{$21 \alpha$-Muurolene $e^{\mathrm{c}, \mathrm{d}}$} & \multirow{3}{*}{1505} & Dry & 1.8 & 0.60 & $1.1 \mathrm{~A}$ \\
\hline & & Wet & - & 0.58 & $0.30 \mathrm{~A}$ \\
\hline & & Average & $0.73 \mathrm{a}$ & $0.59 \mathrm{a}$ & \\
\hline \multirow{3}{*}{$22 \alpha$-Bulnesene ${ }^{d}$} & \multirow{3}{*}{1511} & Dry & 1.3 & 1.9 & $1.6 \mathrm{~A}$ \\
\hline & & Wet & 0.18 & 1.8 & $1.0 \mathrm{~B}$ \\
\hline & & Average & $0.62 \mathrm{a}$ & $1.9 \mathrm{a}$ & \\
\hline \multirow{2}{*}{$23 \delta$-Amorphene } & \multirow{2}{*}{1513} & Dry & 0.14 & - & \\
\hline & & Wet & 0.17 & - & \\
\hline \multirow{3}{*}{$24 \gamma$-Cadinene $^{c}$} & \multirow{3}{*}{1516} & Dry & 11 & 0.36 & $5.0 \mathrm{~A}$ \\
\hline & & Wet & 16 & 0.73 & $8.0 \mathrm{~A}$ \\
\hline & & Average & $14 \mathrm{a}$ & $0.56 \mathrm{~b}$ & \\
\hline \multirow{3}{*}{25 7-epi- $\alpha$-Selinene ${ }^{e}$} & \multirow{3}{*}{1522} & Dry & 0.86 & 1.6 & $1.3 \mathrm{~A}$ \\
\hline & & Wet & 0.71 & - & $0.3 \mathrm{~A}$ \\
\hline & & Average & $0.77 \mathrm{a}$ & $0.71 \mathrm{a}$ & \\
\hline \multirow{2}{*}{$26 \delta$-Cadinene $e^{\mathrm{c}, \mathrm{e}}$} & 1524 & Dry & $5.2 \mathrm{Aa}$ & $13 \mathrm{Ab}$ & \\
\hline & 1524 & Wet & $1.6 \mathrm{Ba}$ & $14 \mathrm{Ab}$ & \\
\hline & & Dry & 1.9 & 4.5 & $3.3 \mathrm{~A}$ \\
\hline $\begin{array}{l}27 \text { Caryophyllene } \\
\text { oxidec }^{c}\end{array}$ & 1583 & Wet & 1.8 & 5.1 & $3.5 \mathrm{~A}$ \\
\hline & & Average & $1.8 \mathrm{a}$ & $4.8 \mathrm{~b}$ & \\
\hline & & Dry & 0.60 & 2.9 & $1.9 \mathrm{~A}$ \\
\hline 28 Humulene epoxide & 1610 & Wet & 0.42 & 1.1 & $0.75 \mathrm{~B}$ \\
\hline & & Average & $0.49 \mathrm{a}$ & $1.9 \mathrm{~b}$ & \\
\hline & & Dry & 0.55 & 1.7 & $1.2 \mathrm{~A}$ \\
\hline 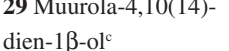 & 1632 & Wet & - & 1.4 & $0.72 \mathrm{~A}$ \\
\hline & & Average & $0.23 \mathrm{a}$ & $1.5 \mathrm{~b}$ & \\
\hline & & Dry & 32 & 18 & $24 \mathrm{~A}$ \\
\hline Monoterpenes $^{\mathrm{d}}$ & & Wet & 33 & 11 & $22 \mathrm{~B}$ \\
\hline & & Average & $33 \mathrm{a}$ & $14 \mathrm{~b}$ & \\
\hline & & Dry & 31 & 16 & $23 \mathrm{~A}$ \\
\hline $\begin{array}{l}\text { Monoterpene } \\
\text { hydrocarbons }\end{array}$ & & Wet & 33 & 11 & $22 \mathrm{~A}$ \\
\hline & & Average & $32 \mathrm{a}$ & $13 \mathrm{~b}$ & \\
\hline & & Dry & 0.95 & 1.3 & $1.1 \mathrm{~A}$ \\
\hline $\begin{array}{l}\text { Oxygenated } \\
\text { monoterpenes }\end{array}$ & & Wet & 0.36 & 0.40 & $0.38 \mathrm{~B}$ \\
\hline & & Average & $0.60 \mathrm{a}$ & $0.78 \mathrm{a}$ & \\
\hline Sesouiternenesd & & Dry & $66 \mathrm{Aa}$ & $78 \mathrm{Ab}$ & \\
\hline sesquiteipenes & & Wet & $60 \mathrm{Aa}$ & $86 \mathrm{Bb}$ & \\
\hline Sesquiterpene & & Dry & $62 \mathrm{Aa}$ & $69 \mathrm{Aa}$ & \\
\hline hydrocarbons & & Wet & $58 \mathrm{Aa}$ & $78 \mathrm{Bb}$ & \\
\hline & & Dry & 3.1 & 9.1 & $6.4 \mathrm{~A}$ \\
\hline $\begin{array}{l}\text { Oxygenated } \\
\text { soguiternenese }\end{array}$ & & Wet & 2.2 & 7.5 & $4.9 \mathrm{~A}$ \\
\hline & & Average & $2.6 \mathrm{a}$ & $8.2 \mathrm{~b}$ & \\
\hline & & Dry & 0.52 & 0.21 & $0.37 \mathrm{~A}$ \\
\hline Yield (\%) & & Wet & 0.61 & 0.18 & $0.40 \mathrm{~A}$ \\
\hline & & Average & $0.57 \mathrm{a}$ & $0.20 \mathrm{a}$ & \\
\hline
\end{tabular}

${ }^{a}$ Average based on original data. ${ }^{b}$ Retention index. ${ }^{\mathrm{c}}$ Constituents selected for PCA (see Experimental section). ${ }^{\mathrm{d}}$ Rank- and ${ }^{\mathrm{e}}$ arcsine-transformed in ANOVA analysis (see Experimental section). Averages followed by the same capital letter in the columns and by the same small letter in the rows did not share significant differences at $5 \%$ probability by Tukey test. 
oxide (27) (4.8\%), and oxygenated sesquiterpene (8.2\%) revealed high amounts in samples from CA seed origin, regardless of the season. Despite the high percentage of $\alpha$-humulene (14) (8.6-13\%), this constituent did not reveal any significant differences between samples from seeds obtained from two different sites and/or season.

Similar relative amounts of such major constituents are reported for clove terpenes from E. caryophyllata Thunb. ${ }^{13}$ Amounts of $\beta$-caryophyllene (10) and $\beta$-caryophyllene oxide (27) over $20 \%$ were reported for essential oils of leaves of E. involucrate DC., E. plicato-costata O. Berg., and E. schuechiana O. Berg., ${ }^{14}$ whereas large amounts of $\alpha$-pinene (1), $\alpha$-copaene (9), $\beta$-caryophyllene (10), and $\alpha$-humulene (14) have been described in leaf oils of $E$. zuchowskiae Barrie. ${ }^{15}$ On the other hand, smaller relative amounts of these compounds were reported in essential oils from leaves of E. tinguyensis Camb., E. rostrifolia Legr., ${ }^{14} E$. caryophyllata and for different chemotypes of E. uniflora L., ${ }^{16}$ and E. Austin-smithii Standl., E. cartagensis O. Berg., E. haberi Barrie, and E. monteverdensis Barrie. ${ }^{15}$

The results obtained from PCA (47 samples $\times 15$ variables $=705$ data; see Table 1 ) and nearest neighbour complete linkage cluster analysis using Ward's technique from PC scores revealed a high chemical variability within the essential oils of $E$. dysenterica. The first PC accounts for $c a .33 \%$ of total variance and separates $(p<0.0001)$ samples originating from $\mathrm{CA}$ seeds (with significant amounts of sesquiterpenes) from samples originating from SC seeds (with significant amounts of monoterpenes), whereas the second PC ( $14 \%$ of total variance) distinguishes $(p<0.0001)$ samples from SC seed origin harvested in the dry season from those of the wet season (Figure 1).

Therefore, two main types of essential oils were found according to seed origin: cluster I included samples originating from SC seeds and cluster II included all samples from CA seed origin. This chemovariation in accordance with seed origin appears to be genetically determined because the variations of the volatile compounds found in the original population were also found in the samples analyzed in this work. ${ }^{10}$ Although samples originating from CA seeds were clustered regardless of the season, samples from SC seed origin appear to be environmentally determined. Here, the SC samples could be enclosed in subcluster IA (SC-dry season samples), characterized by a significantly $(p<0.01)$ high percentage of $\beta$-pinene (2) $(9.3 \pm 2.6 \%), \alpha$-pinene $(\mathbf{1})(9.0 \pm 2.3 \%),(\mathrm{Z})-\beta$-ocimene (5) $(5.9 \pm 4.2 \%), \alpha$-muurolene (21) $(2.6 \pm 2.4 \%)$, and (E)- $\beta$-ocimene (6) $(1.9 \pm 1.0 \%)$; and in subcluster IB (mainly SC-wet season samples) with $\gamma$-cadinene (24) $(17 \pm 11 \%)$, limonene (4) $(14 \pm 9 \%), \beta$-pinene (2) $(8.6 \pm$ $5.4 \%)$, and $\alpha$-neo-clovene (13) $(3.2 \pm 2.1 \%)$ as principal

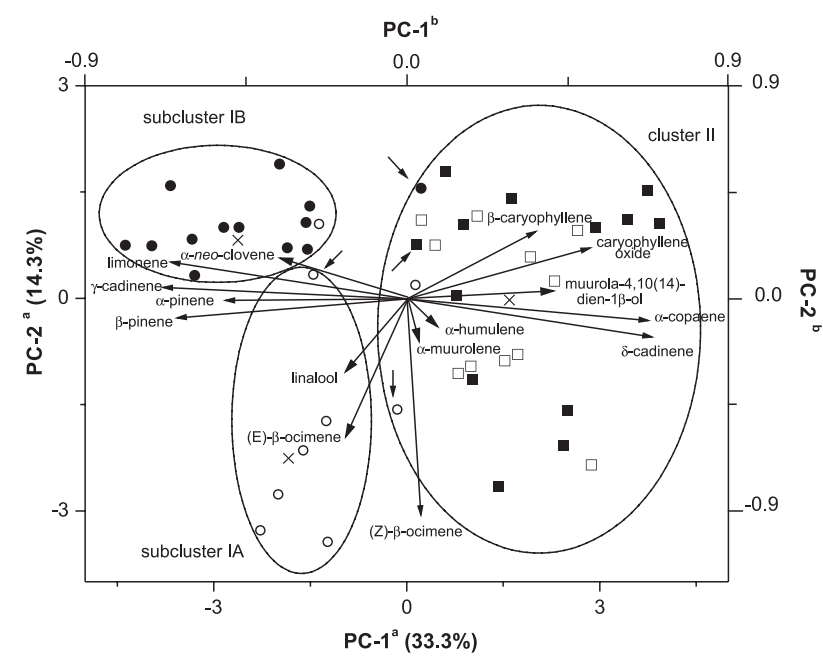

Figure 1. Principal component scatterplot of E. dysenterica cultivated samples originating from seeds from Senador Canedo (SC; circle symbols) and Campo Alegre de Goiás (CA; square symbols); samples collected during dry (unshaded symbols) and wet (shaded symbols) seasons to which subclusters IA/IB and cluster II it belong. "Axes refer to scores from the samples. ${ }^{\mathrm{b}}$ Axes refer to loadings from oil discriminant constituents, represented as long arrows from the origin. Short arrows show misclassified individuals from CDA. Crosses represent cluster centroids and values between parentheses refer to the explained variance on each principal component.

constituents $(p<0.001)$. On the other hand, cluster II included samples originating from CA seeds regardless of the season, which contained significant $(p<0.002)$ amounts of $\beta$-caryophyllene (10) ( $32 \pm 15 \%), \delta$-cadinene (26) (13 $\pm 6 \%$ ), $\alpha$-copaene $(9)(8.1 \pm 4.0 \%)$, caryophyllene oxide (27) $(4.8 \pm 4.4 \%)$, and muurola-4,10(14)-dien-1 $\beta$-ol (29) $(1.4 \pm 1.2 \%)$. Percentages of oil constituents in clustered samples are shown in a supplementary information file. Figure 2 shows the similarities between individuals in terms of Euclidean distances which originated from the Cluster analysis using PC scores.

The hierarchical structure was also considered when the constituent data were coded as independent single character such as presence/absence of terpenes (47 samples $\times 15$ variables/30 modalities), according to a recommendation by Sneath and Sokal. ${ }^{17}$ Although presence/ absence appears to be better suited for the analysis of differences among species, ${ }^{18}$ this approach allows one to assimilate the overall trend in volatile leaf oils and to reduce the uncontrolled factors affecting quantitative variations. Multiple correspondence analyses revealed the same consistent chemical distinction between seasons and sampled populations (data not shown).

The canonical discriminant analysis (CDA) confirmed this clustering as an a priori grouping. The two-dimensional axial system that originated from the CDA distinguished the different types of oils based on the contents of (Z)- $\beta$-ocimene (5), $\gamma$-cadinene (24), and $\delta$-cadinene (26) as 


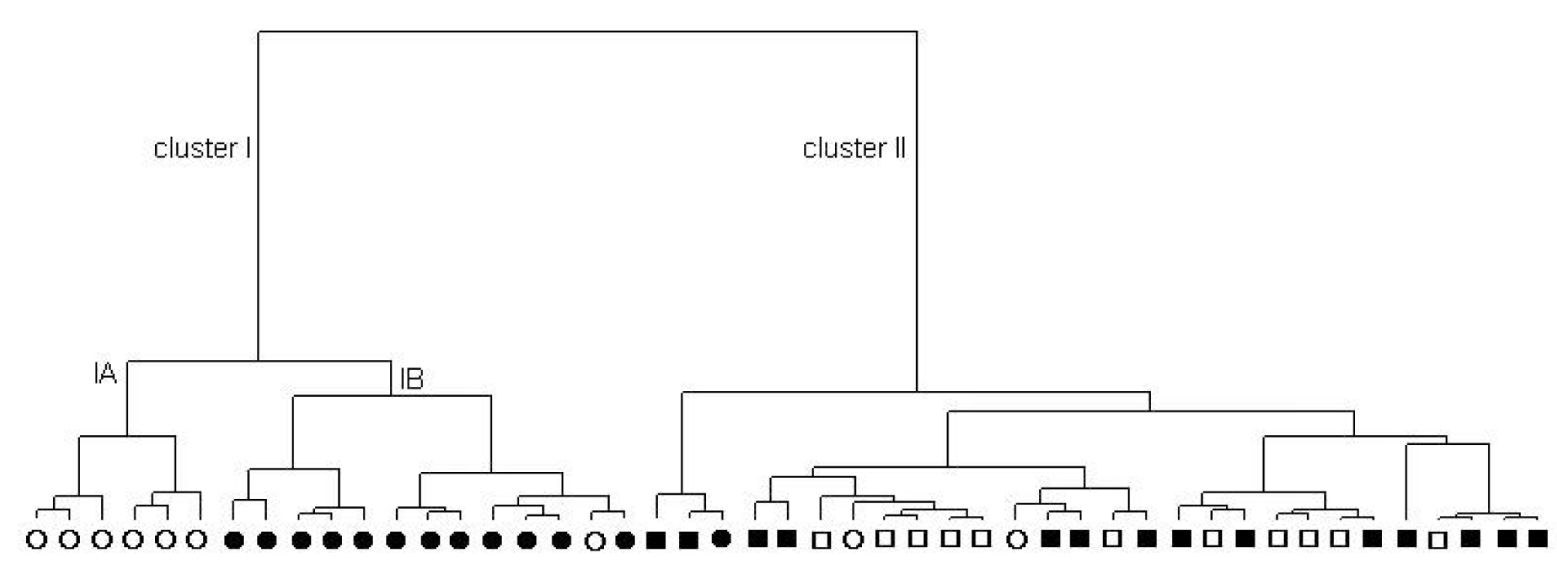

Figure 2. Dendrogram representing chemical composition similarity relationships among 47 cultivated samples of $E$. dysenterica and to which cluster it belongs: I, samples originating from seeds from Senador Canedo (SC; circle symbols); II, samples originating from seeds from Campo Alegre de Goiás (CA; square symbols), collected during dry (unshaded symbols) and wet (shaded symbols) seasons.

predictor variables. The first discriminant function accounts for $87 \%$ of total variability and distinguishes samples originating from SC seeds harvested in the wet season (subcluster IB) and samples from CA seed origin (cluster II) regardless of the season $(F=18.5 ; D F=6$ and 84 ; $p<0.0001)$ due to the high negative and positive scores of $\gamma$-cadinene (24) and $\delta$-cadinene (26), respectively. On the other hand, the second discriminant function distinguishes the population originating from SC seeds harvested in the dry season $(F=9.1 ; D F=2$ and $43 ; p<0.0005)$ as a result of high positive scores of (Z)- $\beta$-ocimene (5) (subcluster IA). In addition, by using the two discriminant functions it is possible to classify correctly $87 \%$ of the samples in the original clusters (four misclassifications) by means of a Jackknife approach. ${ }^{19}$ This involves a number of slightly reduced modifications to the parent data set, estimating parameters from each of these modified data sets and then calculating the accuracy of the predictions by each of the resulting models. The only original mismatched classification was a sample originating from a CA seed (cluster II) which had been classified as belonging to subcluster IB. Such misclassification could be caused by a lower level of $\mathbf{2 6}$ in the sample, which is a feature of plants originating from SC seeds. Two other misclassifications consisted of samples originally clustered as CA (cluster II), although pertaining to the SC (cluster I), in addition to one sample of subcluster IA which was reclassified in subcluster IB.

The observed chemovariations may be correlated with the genetic factor of samples originating from SC and CA seeds (cluster I from cluster II) as well as biotic pressures which could modulate the volatiles of samples cultivated from SC seeds (subclusters IA/IB), such as the influence of pollinators and herbivores or differences in environmental/ seasonal conditions. ${ }^{20}$ In the present work the harvest of winter sample occurred in July, at the end of the dry season, simultaneously to the emission of new leaves and the peak of leafing activities, ${ }^{21}$ with a high capacity for biosynthesized essential oils. Seasonal variations in monoterpene emission rates from Salvia fruticosa Mill have been described and the high emission during spring months was attributed to a self-protection mechanism of the plant's defense from an increase in insect activity. ${ }^{22}$ Other variations include an induced response to herbivore damage in order to recruit predators or herbivore parasites. ${ }^{23}$

In fact, the canonical correlation analysis (Table 2) between populations and climactic factors revealed that $\alpha$-pinene (1), (Z)- $\beta$-ocimene (5), (E)- $\beta$-ocimene (6), bicyclogermacrene (20), humulene epoxide II (28), and oxygenated monoterpenes present a strong relationship with the coldest and driest habitat and are related to winter (subcluster IA). In addition, $\beta$-caryophyllene (10), $\alpha$-amorphene (16), and caryophyllene oxide (27) from the first set and temperature, precipitation, and evaporation from the second set load fairly strongly onto the first canonical variate which is related to the samples originating from CA seeds during the hot and humid summer (cluster II).

These results are in agreement with the findings of a recent study in which the chemical composition of $E$. dysenterica leaf oil from SC and CA wild populations varied considerably. ${ }^{10}$ Other studies have also revealed that contents of the majority of volatile chemical constituents varied significantly in different seasons, such as basil, ${ }^{12}$ rosemary, ${ }^{24}$ Lavandula,${ }^{25}$ mint,${ }^{26}$ and coniferous species. ${ }^{27}$

The observed population structure based on oil variability is in accordance with the results of spatial patterns of genetic variability among $E$. dysenterica populations using morphological and isoenzimatic traits,, 228 as well as simple sequence repeat (SSR) and random- 
Table 2. Canonical correlation summary of oil constituents and climactic factors with their canonical variates

\begin{tabular}{|c|c|c|c|c|c|}
\hline \multirow{2}{*}{ Discriminant oil constituents (set 1 ) } & \multicolumn{2}{|c|}{ Canonical Variate } & \multirow{2}{*}{$\begin{array}{c}\text { Climactic } \\
\text { factors (set 2) }\end{array}$} & \multicolumn{2}{|c|}{ Canonical variate } \\
\hline & Scores & Loadings & & Scores & Loadings \\
\hline $1 \alpha$-Pinene & 0.119 & 0.270 & Temperature $\left({ }^{\circ} \mathrm{C}\right)$ & 0.006 & -1.000 \\
\hline 5 (Z)- $\beta$-Ocimene & -0.221 & 0.409 & Precipitation (mm) & -0.007 & -1.000 \\
\hline 6 (E)- $\beta$-Ocimene & 1.424 & 0.397 & Evaporation (mL) & 0.145 & -1.000 \\
\hline $9 \alpha$-Copaene & 0.108 & 0.166 & Insolation (h) & -0.134 & 1.000 \\
\hline $10 \beta$-Caryophyllene & -0.055 & -0.426 & & & \\
\hline $14 \alpha$-Humulene & -0.118 & 0.129 & & & \\
\hline $16 \alpha$-Amorphene & -0.545 & -0.262 & & & \\
\hline 20 Bicyclogermacrene & 1.228 & 0.432 & & & \\
\hline $24 \gamma$-Cadinene & -0.051 & -0.024 & & & \\
\hline $26 \delta$-Cadinene & -0.123 & 0.089 & & & \\
\hline 27 Caryophyllene oxide & -0.414 & -0.214 & & & \\
\hline 28 Humulene epoxide II & 0.102 & 0.428 & & & \\
\hline 29 Muurola-4,10(14)-dien-1 $\beta$-ol & -0.329 & 0.175 & & & \\
\hline Monoterpene hydrocarbons & -0.065 & 0.116 & & & \\
\hline Oxygenated monoterpenes & 0.317 & 0.551 & & & \\
\hline Sesquiterpene hydrocarbons & 0.309 & 0.005 & & & \\
\hline Oxygenated sesquiterpenes & 0.037 & -0.113 & & & \\
\hline Eingenvalue & & & & 0.832 & \\
\hline Canonical correlation & & & & 0.912 & \\
\hline Wilks' lambda & & & & 0.050 & \\
\hline Degrees of freedom & & & & 68 & \\
\hline$P$-value & & & & 0.003 & \\
\hline \multicolumn{6}{|l|}{ Cumulative variance $(\%)$ : } \\
\hline \multicolumn{3}{|l|}{ of discriminant oil constituent data } & \multicolumn{3}{|c|}{7.2} \\
\hline \multicolumn{3}{|c|}{ of discriminant oil constituents/edapho-climactic relation } & \multicolumn{3}{|c|}{83.1} \\
\hline
\end{tabular}

amplified polymorphic DNA (RAPD) markers. ${ }^{9,29}$ The genetic structure probably originated from a stochastic differentiation process with higher levels of gene flow among closer populations and decreased flow as distances increased, ${ }^{29}$ such as the stepping-stone model. ${ }^{30}$ On the other hand, environmental characteristics among regions exercised a strong influence on population phenotypic differentiation, such as morphological and demographic characters of samples. ${ }^{28}$

\section{Conclusions}

The essential oil variability of $E$. dysenterica determined by GC-MS and allied to multivariate chemometric statistical techniques may reflect a genetic nature in oil composition (SC and CA chemotypes) and indicate that the observed chemical variations may also be caused by selective pressures in the different seasons for samples cultivated from SC seeds (ecotypes).

\section{Experimental}

\section{Plant material}

Leaves of cultivated $E$. dysenterica were collected in July 2006 (dry season) and April 2007 (wet season) from 12-yearold individuals. Leaf samples were obtained from different trees grown from the seeds of the same wild plant, which originated from the two sampling sites of Brazilian Cerrado: Senador Canedo (SC) and Campo Alegre de Goiás (CA). The cultivated individuals were grown in the form of a randomized block with three replications in a single experimental field (S 16 35' 39', W $49^{\circ} 17^{\prime} 23^{\prime \prime}, 716 \mathrm{~m}$ ) belonging to the School of Agronomy and Food Engineering of Universidade Federal de Goiás, Goiânia, Goiás State, Brazil. Voucher (40611 and 40612) specimens are deposited at the Herbarium of Universidade Federal de Goiás (UFG).

In order to assess the chemical composition of oils, leaf samples were collected from 13 different trees grown 
from SC seeds (9 samples collected in the dry season and 13 in the wet season) and 14 different trees grown from CA seeds (11 samples collected in the dry season and 14 in the wet season), all of which were dried for 7 days at $30{ }^{\circ} \mathrm{C}$ until constant weight. After being powdered, each dried phytomass $(50 \mathrm{~g})$ was submitted to hydrodistillation $(3 \mathrm{~h})$ by means of a modified Clevenger-type apparatus. At the end of each distillation oils were collected, dried with anhydrous $\mathrm{Na}_{2} \mathrm{SO}_{4}$, transferred to glass flasks, and kept at a temperature of $-18{ }^{\circ} \mathrm{C}$ until analysis. Oil yields (\%) were based on the dried weight of plant samples. All experiments were conducted in duplicate and the results are shown as mean values.

Mean monthly values of temperature and precipitation were obtained from climatological stations at UFG. The mean values for maximum and minimum temperatures $\left({ }^{\circ} \mathrm{C}\right)$ for the months of July 2006 and April 2007 were $30.0 \pm$ 2.5, $9.9 \pm 1.7$ (average 19.3 \pm 1.7 ) and $32.0 \pm 1.5,16.3 \pm$ 1.1 (average $23.2 \pm 0.9$ ), respectively. The average relative humidity and total rainfall of the months in question were $83.1 \pm 4.2 \%$ and $0.0 \mathrm{~mm}$ and $81.7 \pm 3.5 \%, 129.5 \mathrm{~mm}$, respectively. As regards the climatic data collection, only the relative humidity failed to share significant differences at $5 \%$ probability by Student's $t$ test. The canonical correlation procedure was applied to both data sets concerning essential oil constituents and climactic characteristics.

\section{Chemical analyses}

Oil sample analyses were performed on a GC-MS Shimadzu QP5050A instrument under the following conditions: a CBP-5 (Shimadzu) fused silica capillary column $(30 \mathrm{~m} \times 0.25 \mathrm{~mm}$ i.d., $0.25 \mu \mathrm{m}$ film thickness) connected to a quadrupole detector operating in the EI mode at $70 \mathrm{eV}$ with a scan mass range of $40-400 \mathrm{~m} / \mathrm{z}$ at a sampling rate of 1.0 scan s$^{-1}$; carrier gas: $\mathrm{He}\left(1 \mathrm{~mL} \mathrm{~min}^{-1}\right)$; injector and interface temperatures of $220^{\circ} \mathrm{C}$ and $240{ }^{\circ} \mathrm{C}$, respectively, with a split ratio of 1:20. The injection volume was $0.4 \mu \mathrm{L}$ ( $c$ a. $20 \%$ in hexane) and the oven temperature was raised from $60{ }^{\circ} \mathrm{C}$ to $246{ }^{\circ} \mathrm{C}$ with an increase of $3{ }^{\circ} \mathrm{C} \mathrm{min}{ }^{-1}$, then $10^{\circ} \mathrm{C} \mathrm{min}^{-1}$ to $270^{\circ} \mathrm{C}$, holding the final temperature for $5 \mathrm{~min}$. Individual components were identified by a comparison of their retention indices (RI), ${ }^{31}$ a co-injection with a $\mathrm{C}_{8}-\mathrm{C}_{32}$ n-alkanes series ${ }^{32}$ mass spectra with those of the literature, ${ }^{31}$ and a computerized MS-database using national institute of standards and technology (NIST) libraries.

\section{Chemical variability}

Principal component (PCA) and multiple correspondence analyses were applied in order to examine the interrelationships between populations and their chemical constituents such as amount or presence/absence code, respectively, using système portable d'analyse des Données numériques-SPAD.N software package, version 2.5, Centre International de Statistique et d'Informatique appliquées, France (1994). A cluster analysis was also applied to the study of similarity of samples on the basis of essential oil constituent distribution. Nearest neighbour complete linkage technique by Benzécri algorithm was used as a similarity index and hierarchical clustering was performed according to Ward's variance minimizing method..$^{33}$ For the variable selection, the threshold of residual eigenvalues $(\leq 0.70)$ in the original data matrix (47 samples $\times 29$ variables) was used to establish the maximum number of variables which could be removed (17 variables). ${ }^{34}$ The 14 variables which were effectively eliminated revealed the highest loadings in the lowest residual eigenvalues and also contributed $\leq 2 \%$ to the chemical profiles (average values).

Canonical discriminant analysis using SAS CANDISC procedure (statistical analysis system, SAS institute Inc., Cary, NC, 1996) was used to differentiate populations and clusters on the basis of oil composition. The predictive ability of canonical discriminant functions was evaluated by a Jackknife approach..$^{19}$ Prior to the multivariate analysis, the data was preprocessed by means of auto-scaling and mean centering.

Oil variability and climactic factor relationships were obtained via a canonical correlation analysis implemented using the SAS CANCORR procedure. The predictive ability was evaluated by canonical redundancy analysis with a standardized variance coefficient.

Average multiple comparisons were established by twoway ANOVA (seed origin and season as factors) using SAS GLM analyses. All data were checked for homoscedasticity with the use of Hartley's test. This test revealed significant departures from the basic assumption for the oil constituents $6,8,12,13,17,18,25,26,28$, oxygenated sesquiterpene and 2-4, 10, 11, 21, 22, monoterpenes, monoterpene hydrocarbons and sesquiterpenes, which were arcsine- and rank-transformed, respectively. Whenever a difference was established a post-hoc Tukey's test was performed. Results are shown as mean values and are joined by the standard deviation of independent measurements in some cases. $P$-values below 0.05 were regarded as significant.

\section{Acknowledgements}

The authors are indebted to CNPq, PADCT III and FUNAPE/UFG for financial support. We also acknowledge the anonymous referees for their valuable suggestions for the improvement of this manuscript. 


\section{Supplementary Information}

Supplementary data are available free of charge at http:// jbcs.sbq.org.br, as a PDF file.

\section{References}

1. Johnson, L. A. S.; Briggs, B. G.; Ann. Missouri Bot. Gard. 1984, 71, 700; Landrum, L. R.; Kawasaki, M. L.; Brittonia 1997, 49, 508.

2. Almeida, S. P.; Proença, C. E. B.; Sano, S. M.; Ribeiro, J. F.; Cerrado: Espécies Vegetais Úteis, Embrapa-CPAC: Planaltina, DF, Brazil, 1998.

3. Septímio, L. R.; A Fitoterapia Baseada em Ervas Medicinais do Cerrado, Secretaria de Intercâmbio e Projetos Especiais do Ministério da Cultura: Brasília, Brazil, 1994.

4. Lima, E. O.; Gompertz, O. F.; Giesbrecht, A. M.; Paulo, M. Q.; Mycoses 1993, 36, 333; Souza, L. K. H.; Oliveira, C. M. A.; Ferri, P. H.; Santos, S. C.; Oliveira Júnior, J. G.; Miranda, A. T. B.; Lião, L. M.; Silva, M. R. R.; Braz. J. Microbiol. 2002, 33, 247.

5. Ogunwande, I. A.; Olawore, N. O.; Ekundayo, O.; Walker, T. M.; Schmidt, J. M.; Setzer, W. N.; Int. J. Aromatherapy 2005, $15,147$.

6. Costa, T. R.; Fernandes, O. F. L.; Santos, S. C.; Oliveira, C. M. A.; Lião, L. M.; Ferri, P. H.; Paula, J. R.; Ferreira, H. D.; Sales, B. H. N.; Silva, M. R. R.; J. Ethnopharmacol. 2000, 72, 111.

7. Santos, S. C.; Ferri, P. H.; Ribeiro, J. P.; Guimarães, D. O.; Silva, M. O.; Garcia, A. C. F.; Pires, J. S.; Castro, A. C. M.; Silva, M. R. R.; Paula, J. R.; Rev. Bras. Planta Med. 2004, 7, 30.

8. Telles, M. P. C.; Coelho, A. S. G.; Chaves, L. J.; Diniz-Filho, J. A. F.; Valva, F. D.; Conserv. Genet. 2003, 4, 685.

9. Zucchi, M. I.; Pinheiro, J. B.; Chaves, L. J.; Coelho, A. S. G.; Couto, M. A.; Morais, L. K.; Vencovsky, R.; Pesq. Agropec. Bras. 2005, 40, 975.

10. Duarte, A. R.; MSc Dissertation, Universidade Federal de Goiás, Brazil, 2008; Duarte, A. R.; Costa, A. R. T.; Santos, S. C.; Ferri, P. H.; Paula, J. R.; Naves, R. V.; J. Essent. Oil Res. 2008, 20, 30.

11. Chericoni, S.; Flamini, G.; Campeol, E.; Cioni, P. L.; Morelli, I.; Biochem. Syst. Ecol. 2004, 32, 423; Silva, F. G.; Oliveira, C. B. A.; Pinto, J. E. B. P.; Nascimento, V. E.; Santos, S. C.; Seraphin, J. C.; Ferri, P. H.; J. Braz. Chem. Soc. 2007, 18, 990.

12. Hussain, A. I.; Anwar, F.; Sherazi, S. T. H.; Przybylski, R.; Food Chem. 2008, 108, 986.

13. Zheng, G. Q.; Kenney, P. M.; Lam, L. K. T.; J. Nat. Prod. 1992, 55, 999.

14. Henriques, A. T.; Sobral, M. E.; Cauduro, A. D.; Schapoval, E. E. S.; Bassani, V. L.; Lamaty, G.; Menut, C.; Bessiere, J. M.; J. Essent. Oil Res. 1993, 5, 501.

15. Cole, R. A.; Haber, W. A.; Setzer, N.; Biochem. Syst. Ecol. 2007, $35,877$.
16. Weyerstahl, P.; Weyerstahl, H. M.; Christiansen, C.; Oguntimein, B. O.; Adeoye, A. O.; Planta Med. 1988, 54, 546; Sangwan, N. K.; Verma, B. S.; Verma, K. K.; Dhindsa, K. S.; Pestic. Sci. 1990, 28, 331 .

17. Sneath, P. H.; Sokal, R. R.; Principles of Numerical Taxonomy, W.H. Freeman: San Francisco, 1963.

18. Adams, R. P.; Biochem. Syst. Ecol. 1999, 27, 709.

19. Tukey, J. W.; Ann. Math. Stat. 1958, 29, 614.

20. Sturgeon, K. B.; Evolution 1979, 33, 803; Langenheim, J. H.; J. Chem. Ecol. 1994, 20, 1223; Morais, S. M.; Craveiro, A. A.; Machado, M. I. L.; Alencar, J. W.; Matos, F. J. A.; J. Essent. Oil Res. 1996, 8, 449; Figueiredo, A. C.; Barroso, J. G.; Pedro, L. G.; Scheffer, J. J. C.; In Essential Oils: Basic and Applied Research; Franz, C., Mathe, A., Buchbauer, G., eds.; Allured: Illinois, 1997, p. 95; Robles, C.; Garzino, S.; Phytochemistry 2000, 53, 71; Curado, M. A.; Oliveira, C. B. A.; Jesus, J. G.; Santos, S. C.; Seraphin, J. C.; Ferri, P. H.; Phytochemistry 2006, 67, 2363.

21. Sano, S. M.; Fonseca, C. E. L.; Ribeiro, J. F.; Oga, F. M.; Luiz, A. J. B.; Pesq. Agropec. Bras. 1995, 30, 5.

22. Arey, J.; Crowley, D. E.; Crowley, M.; Resketo, M.; Lester, J.; Atmos. Environ. 1995, 29, 2977.

23. Dicke, M.; Hilker, M.; Bas. Appl. Ecol. 2003, 4, 3; Jurgens, A.; Feldhaar, H.; Feldmeyer, B.; Fiala, B.; Biochem. Syst. Ecol. 2006, 34, 97.

24. Celiktas, O. Y.; Kocabas, E. E. H.; Bedir, E.; Sukan, F. V.; Ozek, T.; Baser, K. H. C.; Food Chem. 2007, 100, 553.

25. Angioni, A.; Barra, A.; Coroneo, V.; Dessi, S.; Cabras, P.; J. Agric. Food Chem. 2006, 54, 4364.

26. Kofidis, G.; Bosabalidis, A.; Kokkini, S.; J. Essent. Oil Res. 2006, 16, 469.

27. Kim, J. C.; Kim, K. J.; Kim, D. S.; Han, J. S.; Chemosphere 2005, 59, 1685.

28. Trindade, M. G.; Chaves, L. J.; Genet. Mol. Biol. 2005, 28, 407.

29. Zucchi, M. I.; Brondani, R. P. V.; Pinheiro, J. B.; Chaves, L. J.; Coelho, A. S. G.; Vencovsky, R.; Genet. Mol. Biol. 2003, 26, 449.

30. Kimura, M.; Weiss, G. H.; Genetics 1964, 49, 561.

31. Adams, R. P.; Identification of Essential Oil Components by Gas Chromatography/Mass Spectrometry, $4^{\text {th }}$ ed., Allured: Illinois, 2007.

32. Van Den Dool, H.; Kratz, P. D. J. A.; J. Chromatogr. 1963, 11, 463.

33. Ward, J. H.; J. Am. Stat. Assoc. 1963, 58, 238; Benzécri, J. P.; L'Analyse des Données: la Taxinomie, Tome 1, Dunod: Paris, 1980.

34. Mardia, K. V.; Kent, J. T.; Bibby, J. M.; Multivariate Analysis, Academic Press: London, 1980.

Received: June 10, 2008 Web Release Date: April 30, 2009 


\section{Seasonal Influence on the Essential Oil Variability of Eugenia dysenterica}

\section{Alessandra R. Duarte, ${ }^{a}$ Ronaldo R. Naves, ${ }^{b}$ Suzana C. Santos, ${ }^{a}$ José C. Seraphin, ${ }^{c}$ and Pedro H. Ferri ${ }^{*}, a$ \\ ${ }^{a}$ Laboratório de Bioatividade Molecular, Instituto de Química, Universidade Federal de Goiás, CP 131, 74001-970 Goiânia-GO, Brazil}

${ }^{b}$ Setor de Horticultura, Escola de Agronomia e de Engenharia de Alimentos, Universidade Federal de Goiás, CP 131, 74001-970 Goiânia-GO, Brazil

${ }^{c}$ Núcleo de Estatística Aplicada, Instituto de Matemática e Estatística, Universidade Federal de Goiás, CP131, 74001-970 Goiânia-GO, Brazil
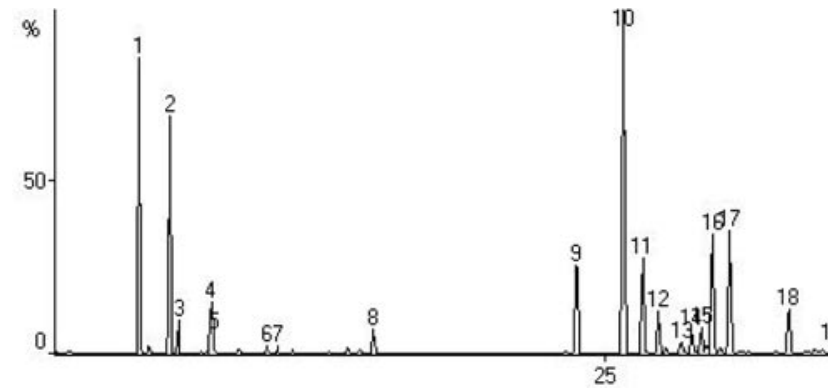

Figure S1. Total ion chromatogram (TIC) of essential oil from E. dysenterica leaves cultivated from seeds from Senador Canedo (SC) and collected during winter.

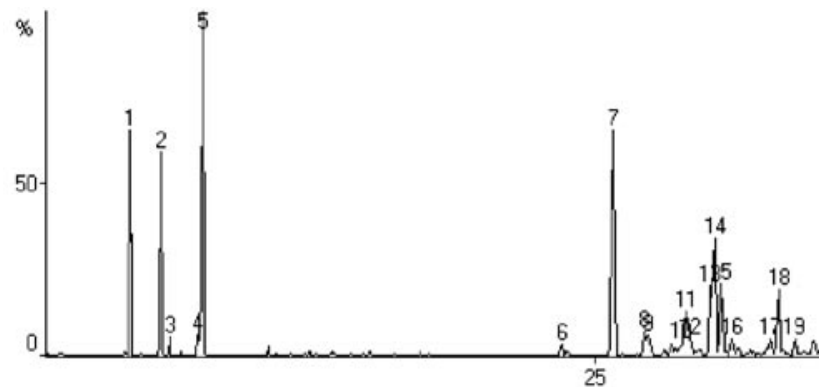

Figure S2. Total ion chromatogram (TIC) of essential oil from E. dysenterica leaves cultivated from seeds from Senador Canedo (SC) and collected during summer.

*e-mail: pedro@quimica.ufg.br 


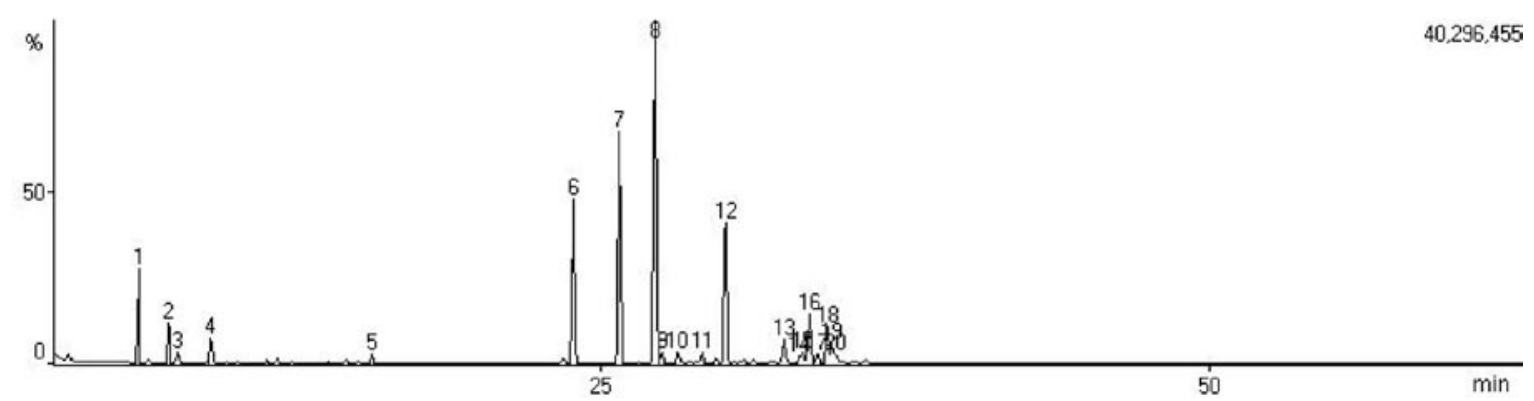

Figure S3. Total ion chromatogram (TIC) of essential oil from E. dysenterica leaves cultivated from seeds from Campo Alegre de Goiás (CA) and collected during winter.

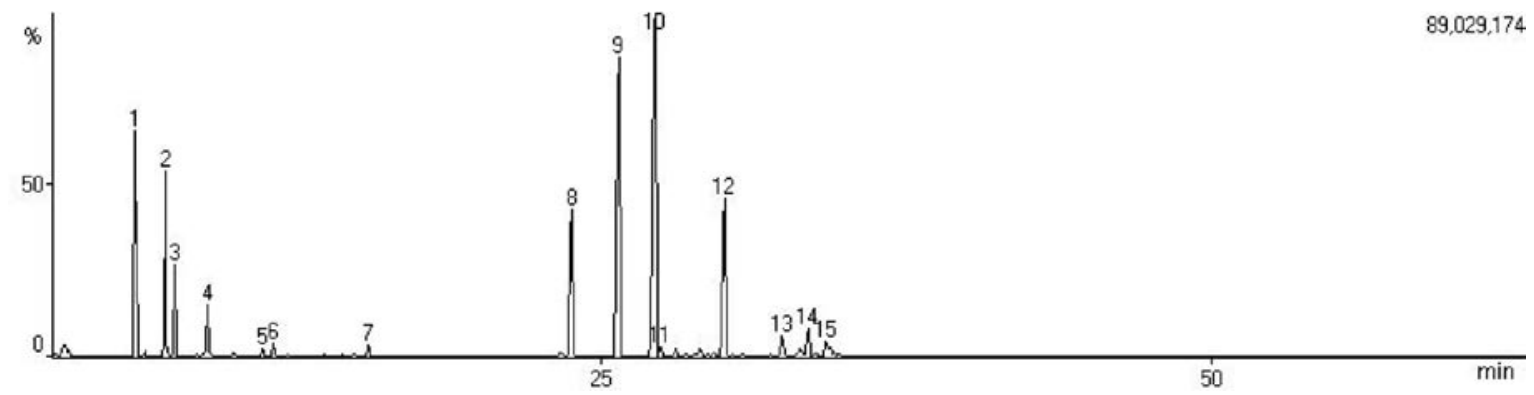

Figure S4. Total ion chromatogram (TIC) of essential oil from E. dysenterica leaves cultivated from seeds from Campo Alegre de Goiás (CA) and collected during summer.

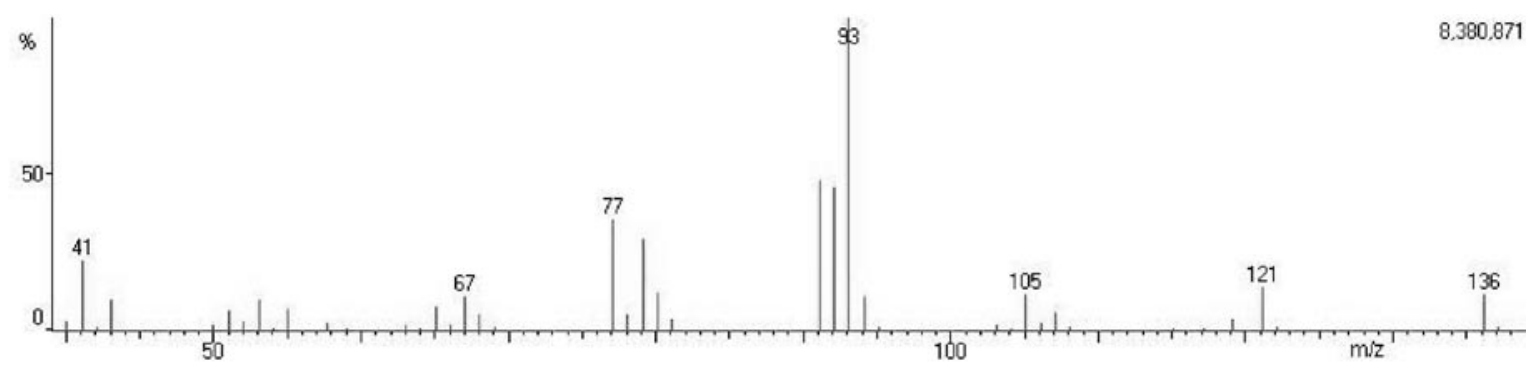

Figure S5. Mass spectrum of $\alpha$-pinene.

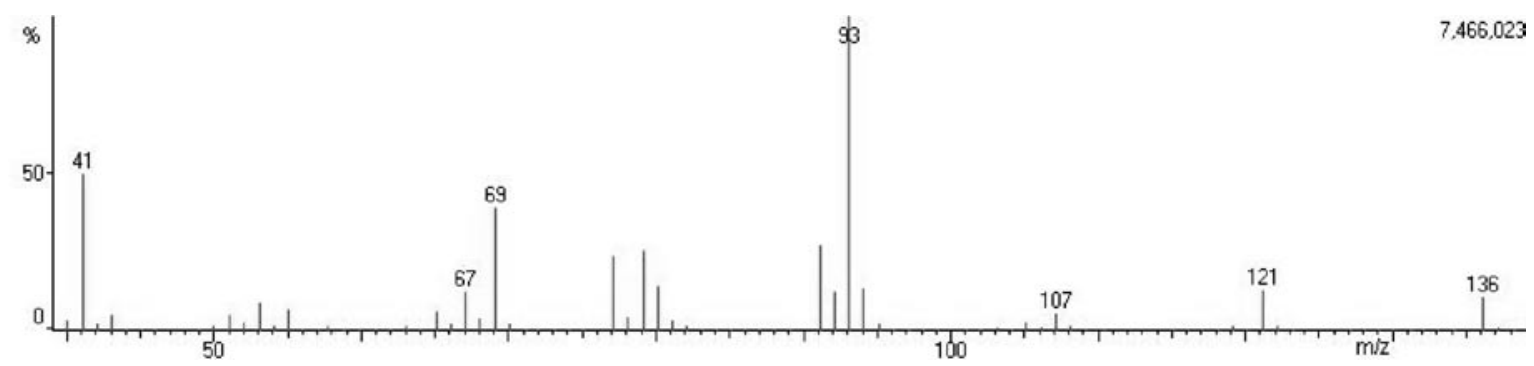

Figure S6. Mass spectrum of $\beta$-pinene. 
Vol. 20, No. 5, 2009

Duarte et al.

SB

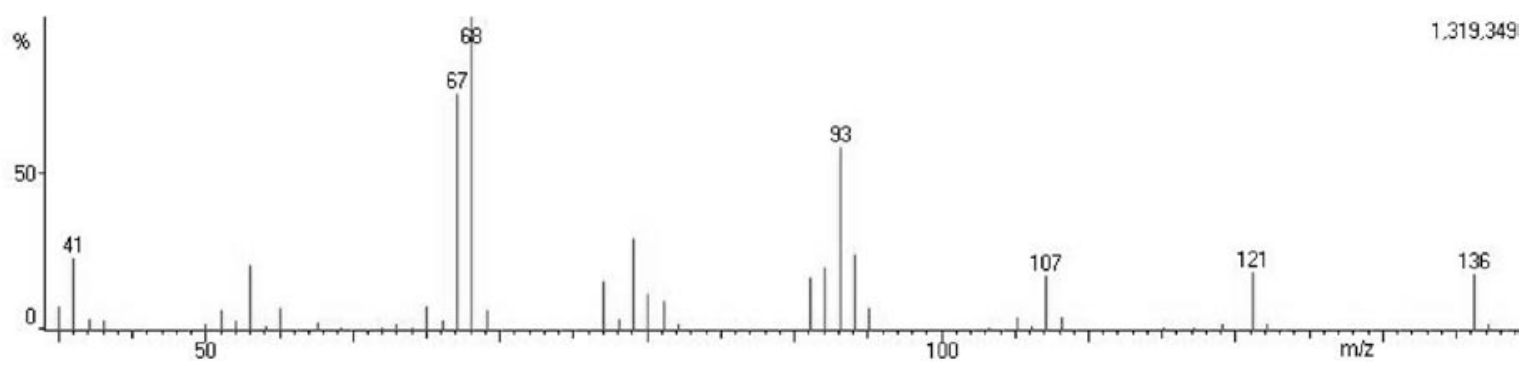

Figure S7. Mass spectrum of limonene.

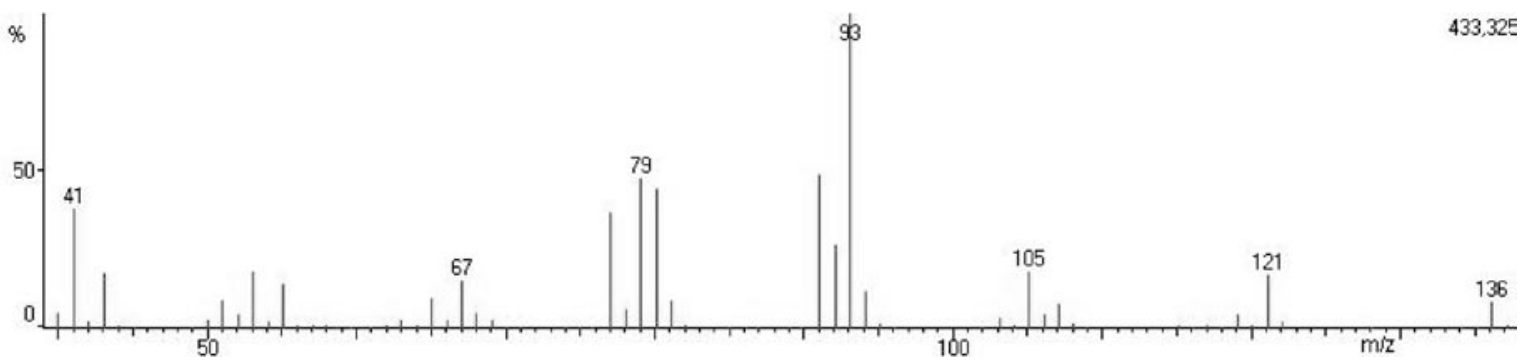

Figure S8. Mass spectrum of (Z)- $\beta$-ocimene.

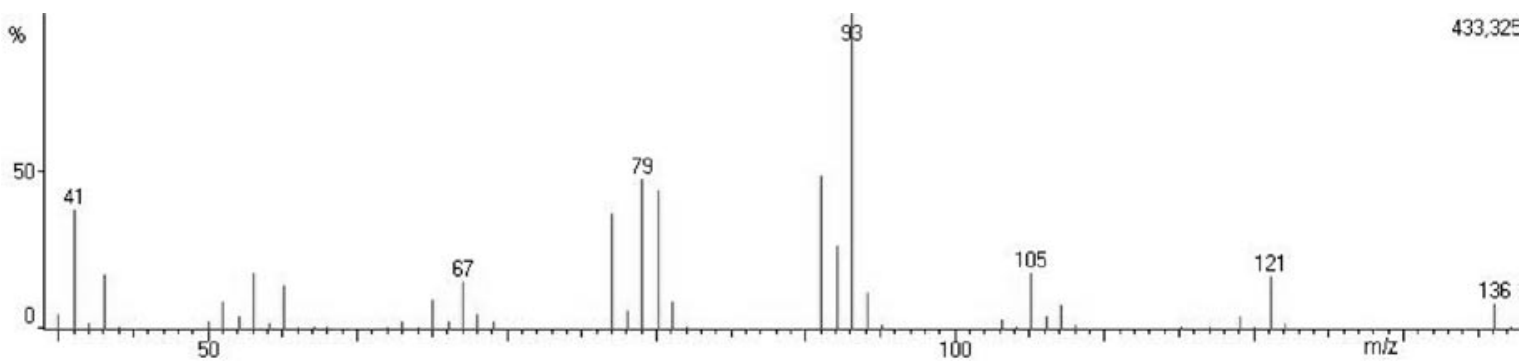

Figure S9. Mass spectrum of $\alpha$-copaene.

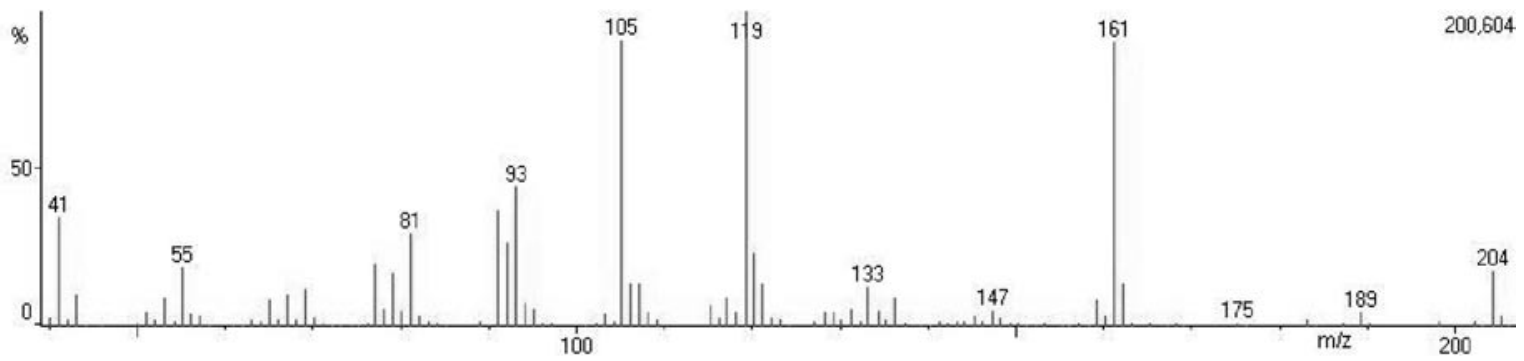

Figure S10. Mass spectrum of $\beta$-caryophyllene. 


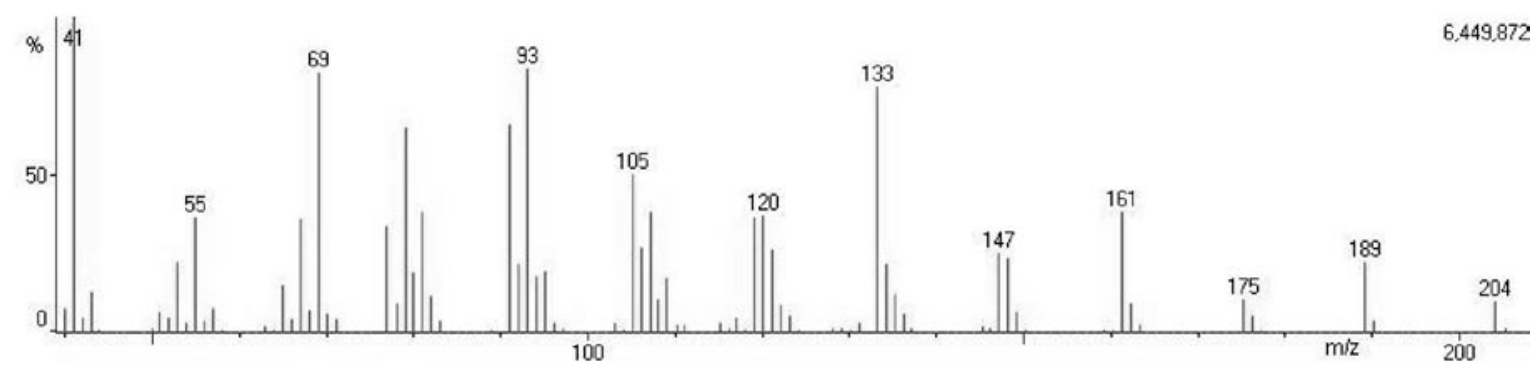

Figure S11. Mass spectrum of $\alpha$-humulene.

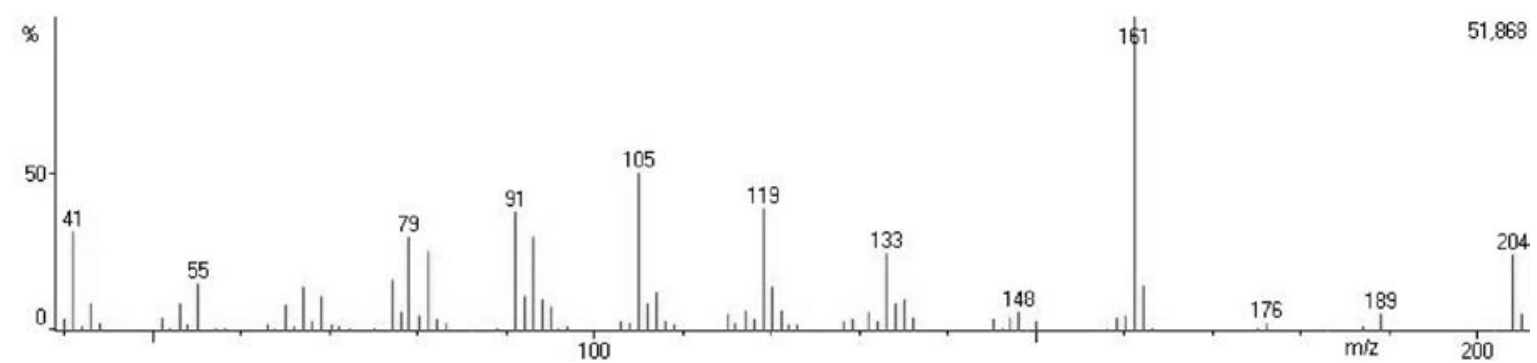

Figure S12. Mass spectrum of $\gamma$-cadinene.

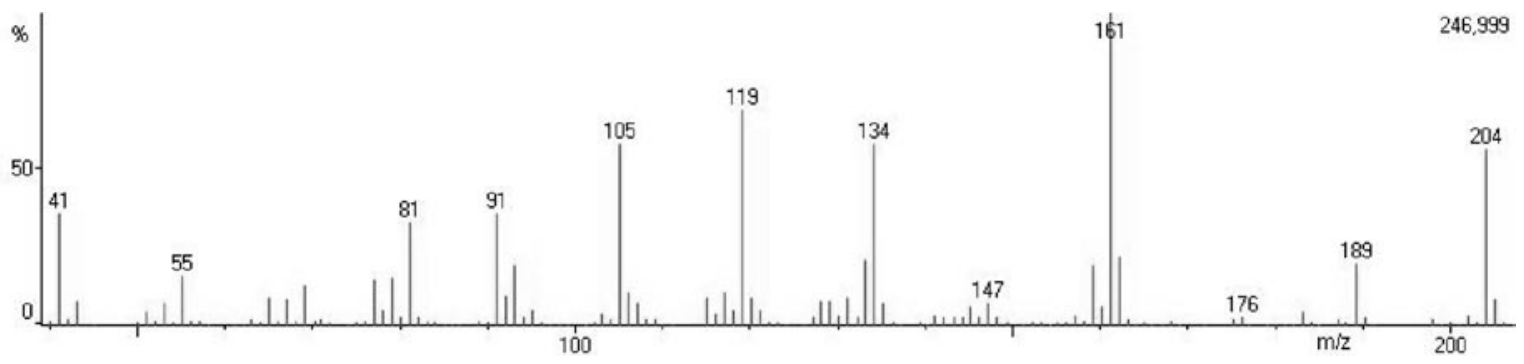

Figure S13. Mass spectrum of $\delta$-cadinene.

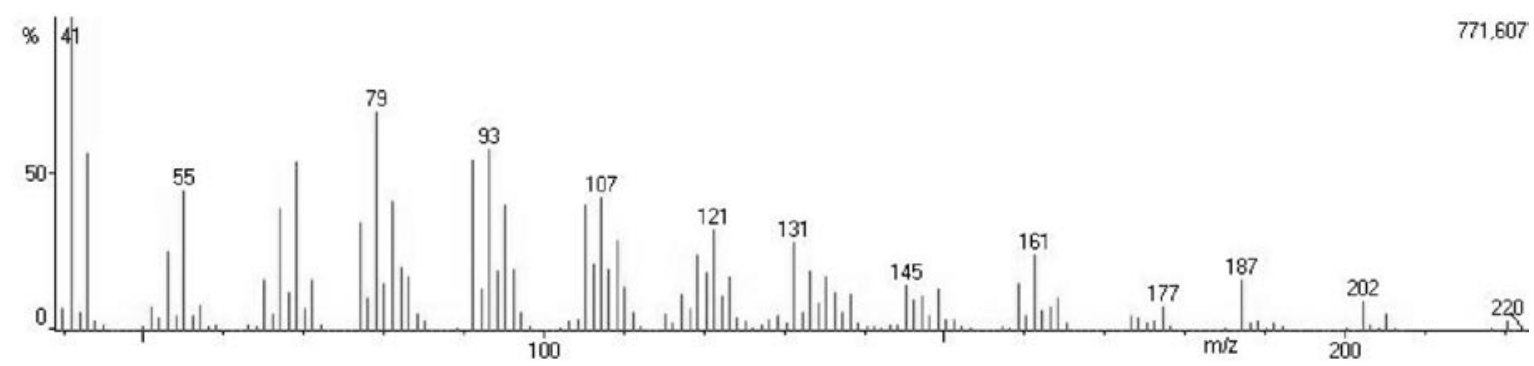

Figure S14. Mass spectrum of caryophyllene oxide. 
Table S1. Percentages ${ }^{\text {a }}$ of essential oil constituents in clustered samples of $E$. dysenterica from seeds obtained from two different sites and collected during dry and wet seasons in the Brazilian Cerrado.

\begin{tabular}{|c|c|c|c|c|}
\hline & \multirow{2}{*}{$\begin{array}{l}\text { Constituent } \\
\text { IA }\end{array}$} & \multicolumn{3}{|l|}{ Clusters } \\
\hline & & IB & II & \\
\hline 1 & $\alpha$-Pinene & $9.0 \pm 2.3 \mathrm{a}$ & $7.8 \pm 3.9 \mathrm{ab}$ & $5.5 \pm 3.1 \mathrm{~b}$ \\
\hline 2 & $\beta$-Pinene ${ }^{b}$ & $9.3 \pm 2.6 \mathrm{a}$ & $8.6 \pm 5.4 \mathrm{a}$ & $3.7 \pm 2.1 \mathrm{~b}$ \\
\hline 3 & Myrcene $^{b}$ & $1.0 \pm 0.5 \mathrm{a}$ & $2.9 \pm 4.8 \mathrm{a}$ & $0.80 \pm 0.80 \mathrm{a}$ \\
\hline 4 & Limonene $^{\mathrm{b}}$ & $7.8 \pm 5.9 \mathrm{a}$ & $14 \pm 9 \mathrm{a}$ & $1.5 \pm 1.3 \mathrm{~b}$ \\
\hline 5 & (Z)- $\beta$-Ocimene & $5.9 \pm 4.2 \mathrm{a}$ & $\mathrm{t}$ & $2.1 \pm 2.9 \mathrm{~b}$ \\
\hline 6 & $(\mathrm{E})-\beta$-Ocimene ${ }^{\mathrm{c}}$ & $1.9 \pm 1.0 \mathrm{a}$ & $0.56 \pm 0.42 b$ & $0.48 \pm 0.64 \mathrm{~b}$ \\
\hline 7 & Linalool $^{\mathrm{b}}$ & $0.50 \pm 0.15 \mathrm{a}$ & $0.27 \pm 0.32 \mathrm{a}$ & $0.27 \pm 0.32 \mathrm{a}$ \\
\hline 8 & $\alpha$-Terpineol $^{\mathrm{b}}$ & $0.27 \pm 0.24 \mathrm{ab}$ & $0.09 \pm 0.22 \mathrm{a}$ & $0.57 \pm 0.66 \mathrm{~b}$ \\
\hline 9 & $\alpha$-Copaene $^{\mathrm{b}}$ & $2.3 \pm 1.3 \mathrm{a}$ & $0.17 \pm 0.51 \mathrm{~b}$ & $8.1 \pm 4.0 \mathrm{c}$ \\
\hline 10 & $\beta$-Caryophyllene ${ }^{c}$ & $18 \pm 7 \mathrm{a}$ & $20 \pm 12 \mathrm{a}$ & $32 \pm 15 b$ \\
\hline 11 & $\alpha$-Guaiene ${ }^{b}$ & $0.40 \pm 0.44 \mathrm{a}$ & $0.40 \pm 0.99 \mathrm{a}$ & $1.3 \pm 2.2 \mathrm{a}$ \\
\hline 12 & 6,9-Guaiadiene & $1.6 \pm 1.0 \mathrm{a}$ & $1.3 \pm 0.9 \mathrm{a}$ & $0.34 \pm 0.90 \mathrm{~b}$ \\
\hline 13 & $\alpha-n e o-C l o v e n e$ & $1.9 \pm 0.8 \mathrm{a}$ & $3.2 \pm 2.1 \mathrm{a}$ & $0.52 \pm 0.94 \mathrm{~b}$ \\
\hline 14 & $\alpha$-Humulene & $11 \pm 5 \mathrm{a}$ & $8.7 \pm 7.7 \mathrm{a}$ & $12 \pm 10 \mathrm{a}$ \\
\hline 15 & $\gamma$-Muurolene ${ }^{c}$ & $0.47 \pm 0.30 \mathrm{a}$ & $0.06 \pm 0.15 b$ & $0.64 \pm 0.64 \mathrm{a}$ \\
\hline 16 & $\alpha$-Amorphene $\mathrm{e}^{\mathrm{b}}$ & $0.02 \pm 0.05 \mathrm{a}$ & $0.27 \pm 0.65 \mathrm{a}$ & $0.09 \pm 0.35 \mathrm{a}$ \\
\hline 17 & $\beta$-Selinene ${ }^{c}$ & $0.74 \pm 1.2 \mathrm{a}$ & $0.26 \pm 0.424 \mathrm{a}$ & $0.32 \pm 0.58 \mathrm{a}$ \\
\hline 18 & $\delta$-Selinene & $2.1 \pm 2.7 \mathrm{a}$ & $2.1 \pm 3.0 \mathrm{a}$ & $1.4 \pm 3.7 \mathrm{a}$ \\
\hline 19 & $\alpha$-Selinene & $0.63 \pm 1.1 \mathrm{a}$ & $0.37 \pm 0.74 \mathrm{a}$ & $0.49 \pm 073 \mathrm{a}$ \\
\hline 20 & Bicyclogermacrene & $0.53 \pm 0.20 \mathrm{a}$ & $0.19 \pm 0.45 \mathrm{a}$ & $\mathrm{t}$ \\
\hline 21 & $\alpha$-Muurolene & $2.6 \pm 2.4 \mathrm{a}$ & $\mathrm{t}$ & $0.54 \pm 0.45 \mathrm{a}$ \\
\hline 22 & $\alpha$-Bulnesene ${ }^{b}$ & $0.18 \pm 0.20 \mathrm{a}$ & $0.53 \pm 1.3 \mathrm{a}$ & $1.9 \pm 3.5 \mathrm{a}$ \\
\hline 23 & $\delta$-Amorphene & $0.12 \pm 0.13 \mathrm{a}$ & $0.21 \pm 0.35 \mathrm{a}$ & - \\
\hline 24 & $\gamma$-Cadinene & $11 \pm 5 \mathrm{a}$ & $17 \pm 11 \mathrm{a}$ & $0.80 \pm 1.6 \mathrm{~b}$ \\
\hline 25 & 7-epi- $\alpha$-Selinene & $0.87 \pm 1.4 \mathrm{a}$ & $0.71 \pm 2.6 \mathrm{a}$ & $0.73 \pm 1.9 \mathrm{a}$ \\
\hline 26 & $\delta$-Cadinene ${ }^{c}$ & $4.4 \pm 1.9 \mathrm{a}$ & $2.0 \pm 1.5 \mathrm{a}$ & $13 \pm 6 b$ \\
\hline 27 & Caryophyllene oxide ${ }^{\mathrm{b}}$ & $1.6 \pm 0.7 \mathrm{a}$ & $1.4 \pm 1.2 \mathrm{a}$ & $4.8 \pm 4.4 \mathrm{~b}$ \\
\hline 28 & Humulene epoxide II & $0.82 \pm 0.42 \mathrm{a}$ & $0.46 \pm 0.74 \mathrm{a}$ & $1.7 \pm 1.8 \mathrm{~b}$ \\
\hline \multirow[t]{7}{*}{29} & Muurola-4,10(14)-dien-1 $\beta$-ol & $0.51 \pm 0.62 \mathrm{a}$ & - & $1.4 \pm 1.2 \mathrm{a}$ \\
\hline & Monoterpenes & $36 \pm 8 \mathrm{a}$ & $34 \pm 12 \mathrm{a}$ & $15 \pm 7 \mathrm{~b}$ \\
\hline & Monoterpene hydrocarbons ${ }^{c}$ & $35 \pm 8 \mathrm{a}$ & $34 \pm 12 \mathrm{a}$ & $14 \pm 6 b$ \\
\hline & Oxygenated monoterpenes & $0.77 \pm 0.28 \mathrm{a}$ & $0.36 \pm 0.41 \mathrm{a}$ & $0.83 \pm 0.82 \mathrm{a}$ \\
\hline & Sesquiterpenes & $62 \pm 8 \mathrm{a}$ & $60 \pm 11 \mathrm{a}$ & $82 \pm 7 b$ \\
\hline & Sesquiterpene hydrocarbons & $59 \pm 8$ a & $58 \pm 11$ a & $74 \pm 8 b$ \\
\hline & Oxygenated sesquiterpenes ${ }^{\mathrm{b}}$ & $2.9 \pm 1.3 \mathrm{a}$ & $1.9 \pm 1.3 \mathrm{a}$ & $7.9 \pm 5.2 \mathrm{~b}$ \\
\hline
\end{tabular}

${ }^{\mathrm{a}}$ Average based on original data \pm standard deviation. ${ }^{\mathrm{b}}$ Rank- and ${ }^{\mathrm{c}}$ arcsine-transformed in ANOVA analysis. t: trace. IA: only SC seed origin-dry season samples; IB: majority SC seed origin-wet season samples; II: all samples from CA seed origin regardless of season (see text). Averages followed by the same letter in a row did not share significant differences at $5 \%$ probability by Tukey's test. 